\title{
EFEK MENGKONSUMSI MINUMAN BERALKOHOL TERHADAP KADAR TRIGLISRIDA
}

\author{
${ }^{1}$ Dwi Purbayanti, ${ }^{1}$ Nur Aryanti Rembulan Saputra \\ ${ }^{1}$ Program Studi Analis Kesehatan, Universitas Muhammadiyah Palangkaraya \\ Email: dwipurbayanti@gmail.com
}

\begin{abstract}
ABSTRAK
Peminum berat yang mengkonsumsi alkohol lebih dari 30 gram per hari akan meningkatkan resiko peningkatan kadar trigliserida. Metabolisme etanol yang kronis menyebabkan oksidasi asam lemak terganggu dan pengalihan karbon menjadi lemak menyebabkan peningkatan produksi trigliserida di hati. Kelebihan trigliserida di hati selanjutnya dikeluarkan kepembuluh darah dan terjadilah penumpukan trigliserida dipembuluh darah dan dapat berlanjut ke Penyakit Jantung Koroner (PJK). Penelitian ini bertujuan untuk mengetahui gambaran kadar trigliserida pada pengguna alkohol di Jalan Mendawai Kota Palangka Raya. Penelitian ini menggunakan metode deskriptif untuk menggambarkan kadar trigliserida pada orang yang menggunakan atau mengkonsumsi alkohol di Jalan Mendawai Kota Palangka Raya. Jumlah sampel yang diperoleh adalah 20 sampel dan diambil menggunakan teknik Purposive Sampling, dengan kriteria yaitu berjenis kelamin laki-laki, berusia lebih dari 20 tahun, sudah mengkonsumsi alkohol lebih dari 5 tahun, minimal 1 kali dalam 1 minggu mengkonsumsi alkohol dan bersedia untuk dijadikan sampel. Hasil penelitian menunjukkan bahwa hanya 1 orang $(5 \%)$ yang memiliki kadar trigliserida normal dan 19 orang (95\%) memiliki kadar trigliserida> normal. Berdasarkan kriteria terhadap risiko penyakit jantung koroner (PJK) yaitu 1 orang (5\%) memiliki kadar trigliserida dengan kriteria ideal, 4 orang (20\%) termasuk dalam kriteria batas tinggi terhadap risiko PJK, 7 orang (35\%) yang termasuk kriteria risiko tinggi dan 8 orang (40\%) yang termasuk kriteria risiko sangat tinggi terhadap PJK.
\end{abstract}

Kata Kunci: Alkohol, PeminumAlkohol, Trigliserida 


\section{PENDAHULUAN}

Alkohol termasuk zat adiktif atau zat yang dapat menimbulkan adiksi (addiction) yaitu ketagihan dan dependensi(ketergantungan).

Penyalahgunaan alkohol adalah masalah kesehatan utama dan juga masalah sosial di masyarakat. Penderita ketergantungan alkohol biasanya memiliki pola konsumsi yang lebih berat dan berakibat pada kerusakan organ yang semakin meluas. Hati dan saluran pencernaan adalah organ utama yang menjadi target kerusakan oleh etanol serta neurologis dan kardiovaskular (Hiramine et al. 2011).

Konsumsi minuman beralkohol dikaitkan dengan peningkatan kejadian banyak penyakit, termasuk sindrom metabolik dan penyakit kardiovaskular (Wakabayashi 2010). Alkohol diketahui memiliki efek pada metabolisme kolesterol lipoprotein densitas tinggi (HDL-C), kolesterol lipoprotein densitas rendah LDL-C dan trigliserida serta tekanan darah (Park dan Kim, 2012).

Sudah lama diketahui bahwa konsumsi alkohol (etanol) mengganggu metabolisme lipid yang menyebabkan disfungsi jaringan adiposa. Konsumsi alkohol kronis mengganggu metabolisme lipid karena meningkatkan lipolisis di jaringan adiposa dan menyebabkan deposisi lemak ektopik di dalam hati dan perkembangan penyakit perlemakan hati (Steiner dan Lang, 2017). Konsumsi etanol sering dikaitkan dengan peningkatan dalam konsentrasi trigliserida plasma dan memiliki relevansi dengan risiko penyakit kardiovaskular dan pankreatitis (Van De Wiel, 2012).

Data epidemiologis dari populasi umum menunjukkan bahwa efek alkohol pada banyak penyakit memiliki pola biphasic atau tergantung pada jumlah konsumsi alkohol. Studi melaporkan bahwa kejadian penyakit jantung koroner (PJK) menurun pada populasi konsumsi alkohol moderat dan kejadian meningkat pada populasi konsumsi alkohol yang berat (Meister et al., 2000). Wakabayashi (2013) melaporkan kadar trigliserida menurun pada konsumsi alkohol yang ringan dan meningkat pada konsumsi alkohol yang berat. Konsumsi etanol berat dapat meningkatkan produk silemak di hati (Sozio dan Crabb, 2008).

Efek akut utama dari konsumsi etanol adalah peningkatan jumlah NADH yang merupakan konsekuensi dari reaksi ADH untuk menghasilkan asetal dehid dan ALDH untuk mengkonversi asetal dehid menjadi asetat. Efek akut yang lain adalah pembentukan senyawa adduct oleh asetal dehida dengan protein, asam nukleat dan senyawa lainnya yang mengakibatkan gangguan aktivitas pada senyawa yang tersebut. Selain itu efek akut akibat metabolisme etanol adalah defisit oksigen (hipoksia) di hati dan pembentukan molekul yang mengandung oksigen sangat reaktif (spesies oksigen reaktif, ROS) yang dapat merusak komponen sel lainnya (King, 2017).

Alkohol (etanol) yang masuk ke dalam tubuh akan mengalami serangkaian 
proses biokimia. Etanol yang dikomsumsi 90\% diantaranya akan dimetabolisme oleh tubuh terutama di hati. Metabolisme etanol di hati menghasilkan penigkatan jumlah nikotinamid adenine dinokleotida dehydrogenase(NADH) sitosolik dan mitokondria yang menyebabkan gangguan pada proses metabolisme normal di hati. Etanol akan dioksidasi akibat mekanisme reaksi alcohol dehydrogenase $(\mathrm{ADH})$ di sitosol menjadi asetaldehid yang bersifat toksik. Didalam mitokondria, asetal dehid akan dioksidasi oleh aldehyde dehydrogenase (ALDH) menjadi asetat. Kelebihan asetat ini diubah menjadi asetil-KoA melalui aksi asetil-CoAsintetase mitokondria dan sitoplasma. Asetil-KoA kemudian dikonversi menjadi asam lemak. Peningkatan trigliserida di dalam hati kemudian dikeluarkan hingga ke pembuluh darah sehingga menyebabkan penumpukan trigliserida di dalam pembuluh darah (King, 2017).

Mempelajari profil lipid pada pasien ketergantungan alkohol sangat bermanfaat, untuk memahami efek dari peningkatan konsumsi alkohol yang dapat menyebabkan konsekuensi kesehatan yang berbeda, seperti penyakit hati alkoholik, penyakit kardiovaskular, dan penyakit ginjal.

\section{METODE PENELITIAN}

Penelitian ini adalah jenis penelitian deskriptif. Sampel yang digunakan adalah peminum alkohol di Jalan Mendawai Kota Palangka Raya yang memenuhi kriteria berjenis kelamin laki-laki, berusia lebih dari 20 tahun, sudah mengkonsumsi alkohol lebih dari 5 tahun, mengkonsumsi alkohol minimal 1 kali dalam 1 minggu,dan bersedia untuk dijadikan sampel. Penarikan sampel dilakukan secara purposive sampling, sehingga diperoleh 20 orang peminum alkohol yang akan dijadikan sampel dalam penelitian ini untuk kemudian dilakukan pengambilan sampel darah dan pemeriksaan kadar trigliserida yang dianalisis di Laboratorium Klinik Fakultas IImu Kesehatan Universitas Muhammadiyah Palangkaraya. Pengukuran kadar trigliserida pada sampel darah vena dilakukan menggunakan fotometer 5010 V5+ Robert Riele dengan metode GPOPAP.

\section{HASIL DAN PEMBAHASAN}

Penelitian yang dilakukan terhadap peminum alkohol di Jalan Mendawai Kecamatan Jekan Raya Kota Palangka Raya, merupakan upaya untuk memberikan gambaran mengenai efek mengkonsumsi alkohol jangka panjang terhadap risiko penyakit kardiovaskular. Subyek yang digunakan dalam penelitian ini adalah peminum alkohol sedang 
hingga berat. Menurut Wiel (2011) dikatakan peminum sedang adalah mengkonsumsi 1-3 gelas perhari bagi lakilaki dan lebih dari 3 gelas perhari merupakan peminum berat. Data hasil penelitian di sajikan dalam tabel 1 dan 2 di bawah ini.

Tabel 1. Rerata Kadar Trigliserida pada Peminum Alkohol

\begin{tabular}{|l|c|c|}
\hline \multicolumn{1}{|c|}{ Karakte ristik } & N & Re rata \pm SD \\
\hline Umur & & \\
\hline $21-30$ tahun & 10 & $319,6 \pm 223.4$ \\
\hline $31-40$ tahun & 6 & $453,3 \pm 310,1$ \\
\hline $41-50$ tahun & 4 & $513 \pm 146,3$ \\
\hline Lama Kons umsi & & \\
\hline 6-10 tahun & 8 & $348,5 \pm 231.9$ \\
\hline $11-15$ tahun & 7 & $340,7 \pm 240,5$ \\
\hline$>15$ tahun & 5 & $559 \pm 240,4$ \\
\hline Durasi & & \\
\hline Selalu (setiap hari) & 4 & $406,6 \pm 233.3$ \\
\hline $2-3$ kali dalam 1 minggu & 16 & $233,3 \pm 318.6$ \\
\hline Kandungan Alkohol dalam Miras & & \\
\hline 1-5\% & 3 & $335,7 \pm 251.9$ \\
\hline 20-50\% & 17 & $409.5 \pm 248,2$ \\
\hline
\end{tabular}

Dari tabel 1 Berdasarkan kelompok umur, terlihat terjadi peningkatan kadar trigliserida seiring bertambahnya usia. Selain itu, terlihat bahwa peminum alkohol yang sudah mengkonsumsi alkohol> 15 tahun memiliki kadar trigliserida lebih tinggi dibandingkan yang kurang dari 15 tahun. Berdasarkan durasi minum, terlihat bahwa peminum yang setiap hari mengkonsumsi alkohol memiliki kadar trigliserida lebih tinggi atau peminum berat memiliki kadar trigliserida lebih tinggi dibandingkan peminum sedang. Dan dari kandungan alkohol dalam miras yang diminum terlihat bahwa kadar trigliserida lebih tinggi pada peminum yang mengkonsumsi alkohol dengan kadar yang lebih tinggi.

Tabel 2. Hasil Pemeriksaan Kadar Trigliserida Berdasarkan Kriteria Risiko Penyakit Jantung Koroner

\begin{tabular}{|c|c|c|c|c|c|}
\hline \multirow{2}{*}{ Karakteristik } & Ideal & AmbangBtres Tinggi & Tinggi & SangetTinggi & \multirow{2}{*}{$\begin{array}{l}\text { TOTAL } \\
\text { SAMPE }\end{array}$} \\
\hline & $<150 \mathrm{mg} / \mathrm{d}$ & $150-199 \mathrm{mg} / \mathrm{dL}$ & $200-500 \mathrm{mg} / \mathrm{dL}$ & $>500 \mathrm{mg} / \mathrm{dL}$ & \\
\hline \multicolumn{6}{|l|}{ Umur } \\
\hline 21-30tahun & $0(0 \%)$ & $4(20 \%)$ & $2(10 \%)$ & $4(20 \%)$ & $10(50 \%)$ \\
\hline 31- 40tahun & $1(5 \%)$ & $0(0 \%)$ & $2(10 \%)$ & $3(15 \%)$ & $6(30 \%)$ \\
\hline 41- 50tahun & $0(0 \%)$ & $0(0 \%)$ & $3(15 \%)$ & $1(5 \%)$ & $4(20 \%)$ \\
\hline \multicolumn{6}{|l|}{ LamaKonsumi } \\
\hline 6-10tahun & $0(0 \%)$ & $2(10 \%)$ & $2(10 \%)$ & $4(20 \%)$ & $8(40 \%)$ \\
\hline 10- 15tahun & $1(5 \%)$ & $2(10 \%)$ & $2(10 \%)$ & $2(10 \%)$ & $7(35 \%)$ \\
\hline$>15$ tahun & $0(0 \%)$ & $0(0 \%)$ & $3(15 \%)$ & $2(10 \%)$ & $5(25 \%)$ \\
\hline \multicolumn{6}{|l|}{ Duras } \\
\hline Selalu (setiap hari) & $0(0 \%)$ & $1(5 \%)$ & $0(0 \%)$ & $3(15 \%)$ & $4(20 \%)$ \\
\hline 2-3kali dalam1 minggu & $1(5 \%)$ & $3(15 \%)$ & $7(35 \%)$ & $5(25 \%)$ & $16(80 \%)$ \\
\hline \multicolumn{6}{|c|}{ Kandungen Alkohol dalam Mires } \\
\hline $1-5 \%$ & $1(5 \%)$ & $0(0 \%)$ & $1(5 \%)$ & $1(5 \%)$ & $3(15 \%)$ \\
\hline $20-50 \%$ & $0(0 \%)$ & $4(20 \%)$ & $6(30 \%)$ & $7(35 \%)$ & $17(85 \%)$ \\
\hline
\end{tabular}

Catatan : nilai normal trigliserida adalah $<150 \mathrm{mg} / \mathrm{dL}$ 
Pada tabel 2 terlihat dari 20 orang peminum alkohol, hanya 1 orang (5\%) yang masuk kedalam kriteria ideal, 4 orang $(20 \%)$ masuk kriteria ambang batas tinggi, 7 orang (35\%) orang masuk kriteria tinggi dan 8 orang (40\%) masuk kriteria sangat tinggi atau $95 \%$ dari sampel memiliki kadar trigliserida lebih dari normal (hipertrigliserida).

Konsumsi minuman beralkohol mempunyai berbagai efek pada kadar lipid plasma terutama pada peningkatan kadar trigliserida. Konsumsi alkohol dapat menstimulasi hati untuk mensekresikan VLDL, akibat hambatan oksidasi asam lemak bebas di hati, yang akan memicus intesis trigliserida dan sekresi VLDL (Rader, 2006). Hal ini juga dilaporkan Van De Wiel (2012) bahwa asupan alkohol yang berlebihan dapat meningkatkan kadar trigliserida. Alkohol yang dikonsumsi $90 \%$ akan dimetabolisme oleh tubuh terutama didalam hati oleh enzim alkoholdehidrogenase (ADH) dan koenzim nikotinamid-adenin-dinukleotida menjadi asetaldehid dan kemudian oleh enzim aldehida dehidrogenase (ALDH) diubah menjadi asam asetat. Asam asetat dioksidasi menjadi $\mathrm{CO}_{2}$ dan $\mathrm{H}_{2} \mathrm{O}$. Piruvat, levulosa (fruktosa), gliseraldehida (metabolit dari levulosa) dan alanin akan mempercepat metabolisme alkohol. Pemakaian alkohol yang lama juga akan menimbulkan perubahan pada mitokondria yang menyebabkan berkurangnya kapasitas untuk oksidasi lemak (King, 2017)
Berdasarkan umur dari subyek peminum alkohol terlihat data tidakkonsisten, namununtukusia 41 - 50 tahun, semua responden memiliki kadar trigliserida di atas nilai normal atau memiliki risiko yang tinggi dan sangat terhadap PJK. Sedangkan berdasarkan lama konsumsi alkohol, peminum yang mengkonsumsi alkohol lebih dari 15 tahun semua memiliki risiko yang lebih tinggi yakni sebanyak 3 orang (15\%) termasuk kriteria tinggi dan 2 orang (10\%) termasuk kriteria sangat tinggi.Van De Wiel (2012) melaporkan bahwa peminum alkohol kronis dengan dapat meningkatkan aktifitas lipoprotein lipase (LPL) sehingga meningkatkan lipolisis dan peningkatan asam lemak dalam plasma yang berakibat pada peningkatan kadar trigliserida.

Berdasarkan durasi mengkonsumsi alkohol, yang mengkonsumsi alkohol setiap hari lebih banyak memiliki risiko sangat tinggi terhadap PJK dibandingkan yang mengkonsumsi 2 sampai dengan 3 kali dalam 1 minggu. Konsumsi alkohol secara berlebihan dapat meningkatkan penyakit jantung koroner (PJK) dan stroke (3 kali lebih besar) terutama pada anak muda.

Berdasarkan kandungan alkohol dalam minuman keras, terlihat bahwa peminum yang mengkonsumsi minuman dengan kadar alkohol $20-50 \%$ lebih banyak yang memiliki risiko tinggi dan sangat tinggi terhadap PJK. Hal ini sesuai dengan studi yang dilakukan (Hiramine et al., 2011) bahwa semakin banyak jumlah 
konsumsi alkohol, maka kadar trigliserida semakin tinggi.

Penelitian ini menggunakan subyek peminum alkohol dan semua responden adalah perokok. Dan (Fernández-solà, 2015) bahwa merokok memodifikasi hubungan antara minum alkohol dan beberapa faktor risiko aterosklerosis, merokok dapat meningkatkan kadar trigliserida pada peminum alkohol yang merokok di bandingkan yang tidakmerokok (Wakabayashi, 2013).

\section{KESIMPULAN}

Hasil penelitian menunjukkan bahwa hanya 1 orang (5\%) yang memiliki kadar trigliserida normal dan 19 orang (95\%) memiliki kadar trigliserida> normal. Berdasarkan kriteria terhadap risiko penyakit jantung koroner (PJK) yaitu 1 orang $(5 \%)$ memiliki kadar trigliserida dengan kriteria ideal, 4 orang (20\%) termasuk dalam kriteria batas tinggi terhadap risiko PJK, 7 orang (35\%) yang termasuk kriteria risiko tinggi dan 8 orang $(40 \%)$ yang termasuk kriteria risiko sangat tinggi terhadap PJK.

\section{DAFTAR PUSTAKA}

Fernández-solà, J., 2015. moderate and heavy alcohol consumption. Nature Publishing Group, pp.1-12. Available at:

http://dx.doi.org/10.1038/nrcardio.201
5.91.

Hiramine, Y. et al., 2011. Alcohol drinking patterns and the risk of fatty liver in Japanese men. Journal of Gastroenterology, 46(4), pp.519-528. King, MW., 2017. Ethanol metabolism.

Available at:

https://themedicalbiochemistrypage.o rg/ethanol-

metabolism.phpdiaksespada 12

Agustus 2017

Meister, K.A., Whelan, E.M., Kava, R.,2000. The health effects of moderate alcohol intake in humans: an epidemiologic review. Crit Rev ClinLab Sci. 37(3), pp.261-296.

Park, H. \& Kim, K., 2012. Association of alcohol consumption with lipid profile in hypertensive men. Alcohol and Alcoholism, 47(3), pp.282-287.

Rader, D.J. \& Hobbs, H.H., Disorders of Lipoprotein Metabolism.Dalam : Jameson, JL., 2006. Harrison's Endocrinology Ed. 16. United States of America: Library of Congress Cataloging; pp.333-354

Sozio, M. \& Crabb, D.W., 2008. Alcohol and lipid metabolism. AJP: Endocrinology and Metabolism, 295(1), pp.E10-E16. Available at: http://ajpendo.physiology.org/cgi/doi/ 10.1152/ajpendo.00011.2008.

Steiner, J.L. \& Lang, C.H., 2017. Alcohol, adipose tissue and lipid 
dysregulation. Biomolecules, 7(1).

Wakabayashi, I., 2010. Associations between alcohol drinking and multiple risk factors for atherosclerosis in smokers and nonsmokers. Angiology, 61(5), pp.495-503.

Wakabayashi, I., 2013. Relationship between alcohol intake and lipid accumulation product in middle-aged men. Alcohol and Alcoholism, 48(5), pp.535-542.

Van De Wiel, A., 2012. The effect of alcohol on postprandial and fasting triglycerides. International Journal of Vascular Medicine, 2012. 